\title{
Phytoplankton Blooms Weakly Influence the Cloud Forming Ability of Sea Spray Aerosol
}

Douglas B. Collins ${ }^{1, \neq}$, Timothy H. Bertram ${ }^{2}$, Camille M. Sultana ${ }^{1}$, Christopher Lee ${ }^{1}$, Jessica L. Axson $^{1, \|}$, Kimberly A. Prather ${ }^{1,3, *}$
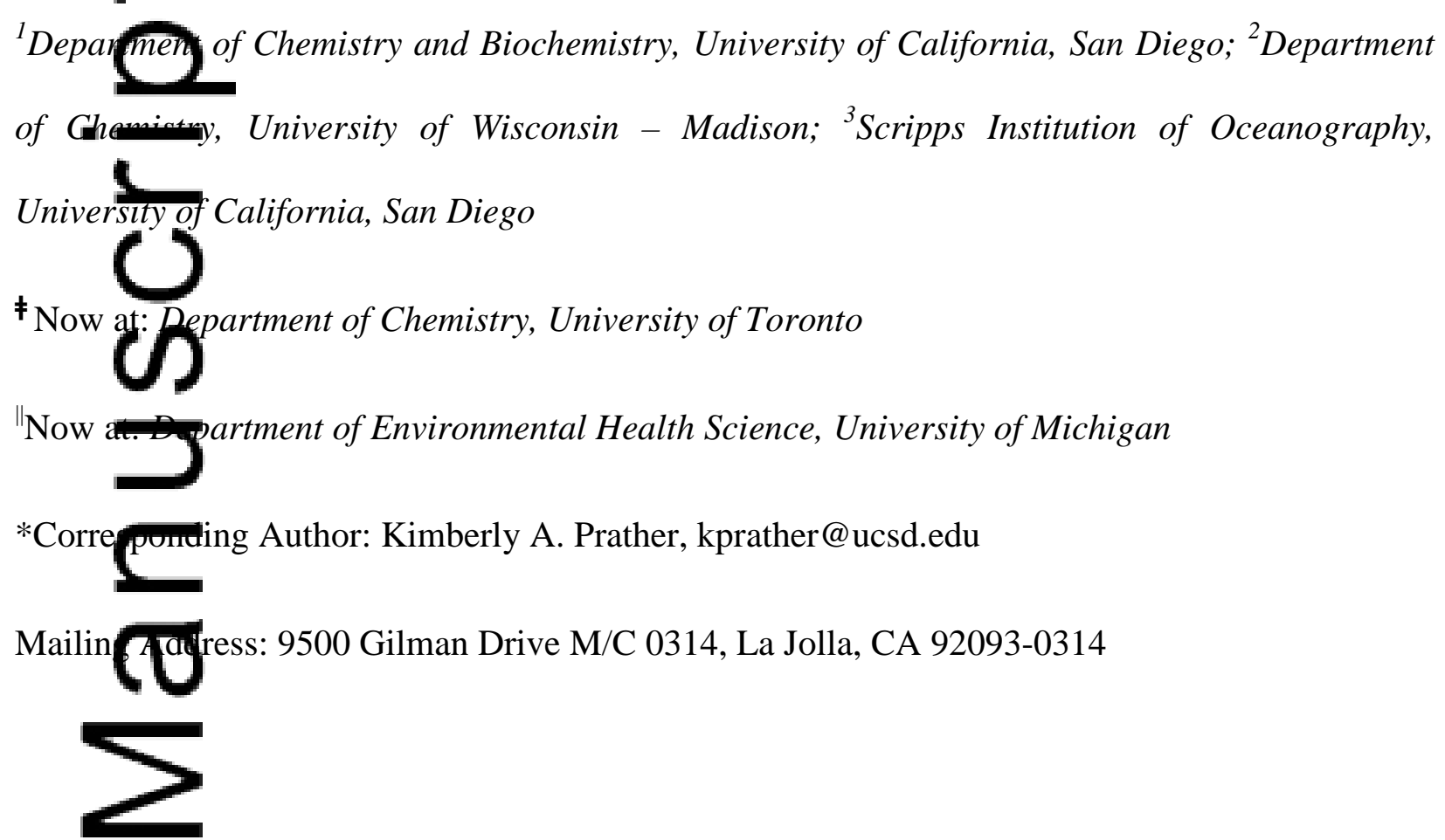

Key Points:

- Changes in seawater and sea spray composition did not strongly affect expected CCN Qnentrations

- Rlooms may impact clouds more strongly through changes in aerosol flux or secondary themistry

- parameterizations likely overestimate changes in cloud nuclei due to primary rine organics

This is the author manuscript accepted for publication and has undergone full peer review but has not been through the copyediting, typesetting, pagination and proofreading process, which may lead to differences between this version and the Version of Record. Please cite this article as doi: 10.1002/2016GL069922

This article is protected by copyright. All rights reserved. 


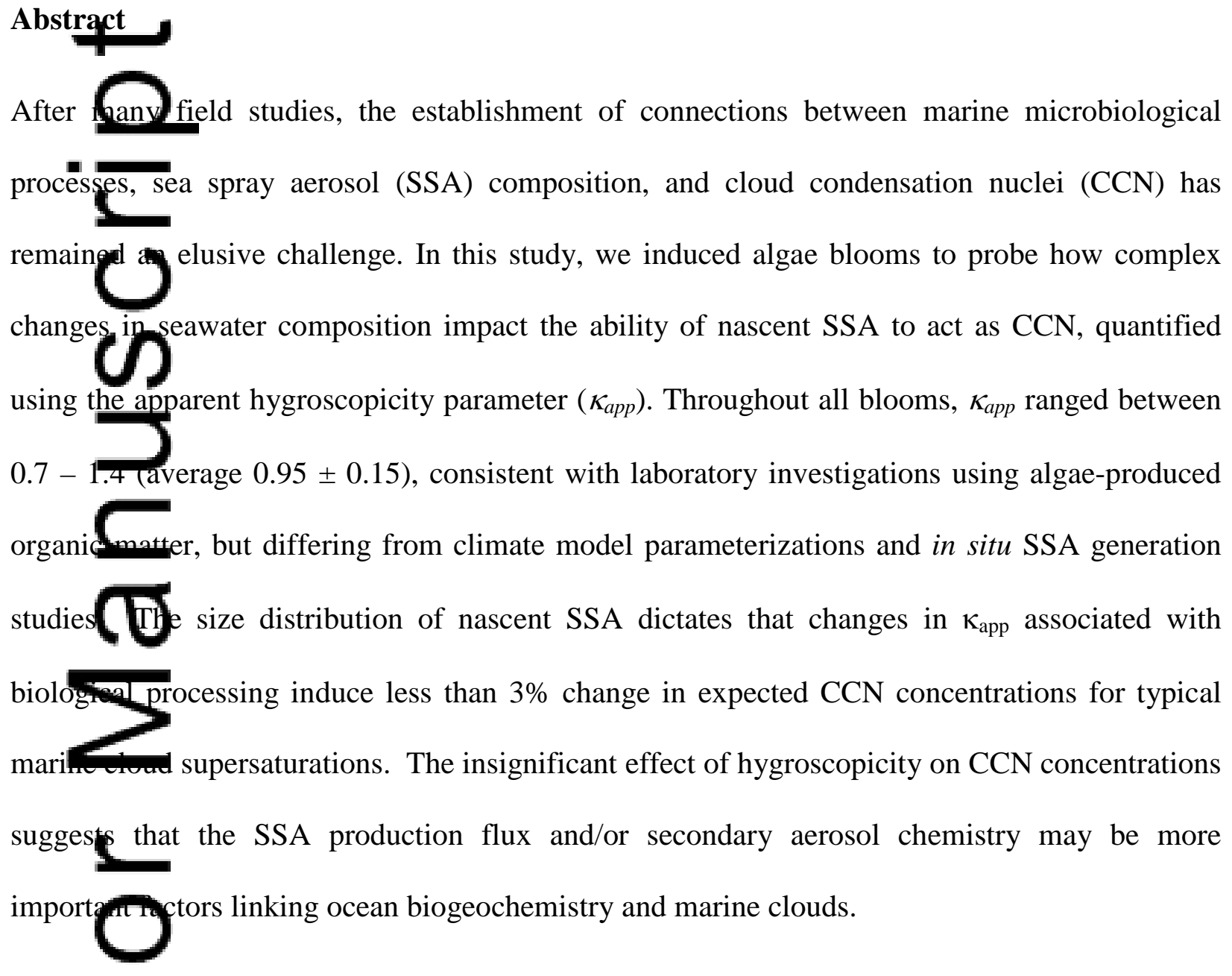

Index cerms: 0305 Aerosols and particles, 0315 Biosphere/atmosphere interactions, 0320 Cloud physicandrandryistry, 0312 Air/sea constituent fluxes, 3311 Clouds and aerosols

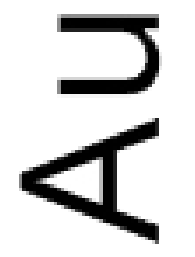




\section{Introduction}

Natural aerosol particles are responsible for the largest contribution to uncertainty in the aerosol indirect effect [e.g., Carslaw et al., 2013; Tsigaridis et al., 2013]. Understanding the properties and concentrations of aerosols that were dominant in the pre-industrial atmosphere is key to unders andihanthropogenic perturbations, since the relationship between aerosol and cloud drople number concentrations is non-linear; sensitivity of cloud droplet concentrations to presentay anthropogenic perturbations rests strongly on the pre-industrial baseline [Ramaratjay et al., 2001]. Sea spray aerosol (SSA) is one of the most abundant types of natural aerosolobahally, and can play an important role in cloud formation and microphysics through their role as cloud condensation nuclei (CCN) [Feingold et al., 1999; Gantt et al., 2012; McCoy

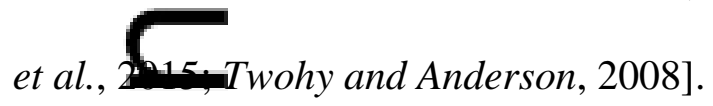

Major ton components of seawater $\left(\mathrm{Na}^{+}, \mathrm{K}^{+}, \mathrm{Mg}^{2+}, \mathrm{Cl}^{-}\right)$have been found within marine cloud droplets any precipitation [Straub et al., 2007; Twohy and Anderson, 2008; Woodcock, 1952] and SSA particles have been shown to influence the properties of marine stratocumulus clouds [Feing st al., 1999], especially in remote regions [Glantz, 2010]. While the chemical compo ition of SSA is highly complex [Quinn et al., 2015], it is often roughly approximated as a mixtur ormorganic and organic species [e.g., Roelofs, 2008] which can be modulated by marine microbialadivity [Ault et al., 2013; O'Dowd et al., 2015; Wang et al., 2015]. Using a simple two-component view of SSA composition and hygroscopicity, global model studies have shown that biog wemical changes within the surface ocean can account for a change in marine CCN 
concentrations between $-5 \%$ and $+50 \%$, depending on how aerosol mixing state and production flux are treated within the models in association with marine microbial activity [Meskhidze et al., 2011; Tsigaridis et al., 2013; Westervelt et al., 2012]. SSA flux and chemical parameterizations woula most complete when informed by chemically and physically realistic experiments that contro anditions around SSA particles specifically, yet attempt to approximate the complexity of marine biogeochemistry. The present study perturbed seawater chemistry through dynamic microbal egosystem processes to examine chemically complex SSA particles [Lee et al., 2015]. Using ( P) phing waterfall method, SSA particles were produced with physicochemical properties_imilar to those produced by breaking waves [Collins et al., 2014; Stokes et al., 2013].

The relative role of chemistry in determining CCN concentrations mostly centers on the magnitude of the change in $\kappa_{\text {app }}$ compared with the magnitude of possible changes in the number size distrivution of aerosol [Dusek et al., 2006]. Rather than focusing on just the average compositio of particles in the atmosphere, Wex et al. [2010a] illustrated conceptually that the mixing state of the chemical components of the aerosol population is a key component of the system has been shown in laboratory [Collins et al., 2013; Schill et al., 2015], field [Cubis net al., 2008; Padro et al., 2012], and modeling studies [Meskhidze et al., 2011; Roelofs, 2008]. The strongest effect of composition in decreasing CCN activity occurs when the abunderticle types with significantly different intrinsic hygroscopicity vary with size and the les hygroscopic particles have smaller dry diameters than the more hygroscopic particlecollins et al., 2013; Wex et al., 2010a]. 
This study aims to constrain the CCN-derived hygroscopicity of SSA as a function of biological activity within a set of laboratory-generated marine phytoplankton bloom experiments [Lee et al., 2015]. Approaching the highly complex chemical system of SSA in a top-down manner is usefurtor gaining an understanding of the ensemble effect of all chemical changes to the system with reseo in this case, to the phase of biological activity in the microcosm. While a predictive unders anding of the cloud activity of SSA requires a detailed understanding of the physical chemis $1 y$ of the activating droplet, this study aims to broadly characterize the response of the CCN deriad hygroscopicity of SSA to marine microbial processes. The relative importance of particle hvoroscopicity in driving expected $\mathrm{CCN}$ concentrations from nascent SSA in the marine boundary layer is discussed and compared with the current climate model paradigm.

\section{Methods}

\subsection{Measurement of the Hygroscopicity Parameter}

The hygroseopicity of nascent SSA particles was measured using size-resolved CCN analysis. A dry, monodisperse aerosol is generated by selecting a specific size with an electrostatic classifier (TSI, Iric., vlodel 3080L) operated with a sheath flow of 5 liters per minute and a total sample flowrat of liter per minute. The monodisperse output of the electrostatic classifier was then split is kinetically to a continuous flow, stream-wise thermal gradient cloud condensation nucleutwanter (CCNC; Droplet Measurement Technologies, Model CCN-100) and a condensatio particle counter (CPC; TSI, Inc., Model 3010). The ratio of particles that activated into clar droplets within the CCNC at a specified supersaturation $(s)$ was used to determine the 
activation diameter $\left(D_{a c t}\right)$ of the aerosol sample where $50 \%$ of the particles are cloud-active. The $D_{a c t}$ and $s$ pairs determined by this method were used to calculate the hygroscopicity parameter ( $\kappa)$ [Petters and Kreidenweis, 2007] using Equation 1:

$$
\kappa_{a p p}=\frac{4 A^{3} \sigma_{l v}^{3}}{27 T^{3} D_{a c t}^{3} \ln ^{2}(s)}
$$

where $=8.69251 \times 10^{-6} \mathrm{~K} \mathrm{~m}^{3} \mathrm{~J}^{-1}$ and $\sigma_{l v}$ is the surface tension of the liquid/vapor interface of the roplt, and $T$ is the temperature. This relatively simple formulation of the hygroscopicity parame an approximation [Petters and Kreidenweis, 2007; 2013], but deviations in $\kappa$ derived this calculation in comparison with numerical methods are much smaller than experimental uncertainties $(\kappa \pm 10 \%)$. While $\kappa$ strictly parameterizes only the Raoult's Law term of the Konler equation [Petters and Kreidenweis, 2007], the surface tension of the activating droplet 1 sumed to be constantly that of pure water $\left(72 \mathrm{mN} \mathrm{m}^{-1}\right)$ for consistency across studies [e.g., Paat al., 2012; Sullivan et al., 2009], as the surface tension of droplets at activation is difficult to quantify [Ruehl et al., 2012]. Especially in cases where droplet surface tension is of potentilimportance to the observations, $\kappa$ is often labeled as 'apparent' $\left(\kappa_{\text {app }}\right)$ [Sullivan et al., 2009] hen surface tension is assumed constant. If changes in surface tension were to impact CCN ctrvation, the coupled influence of the surface tension and solvent activity would be essentivlly llamped together within $\kappa_{a p p}$. The apparent hygroscopicity convention was adopted in this study iif light of the high degree of chemical complexity and the relatively weak degree of physiconimical characterization of SSA particles to date [Quinn et al., 2015]. 


\subsection{Sample Preparation}

This study evaluated the CCN activity of nascent SSA particles generated during a series of marine biological microcosm experiments. The methodology and detailed analysis of certain biologital and chemical aspects of this type of experiment was described in detail by Lee et al. [2015] and explanation will be given here. For each experiment, a sample of natural, coastalseawater was obtained, filtered using $50 \mu \mathrm{m}$ Nitex mesh (Sefar Nitex 03-100/32), and allowe to gquilibrate thermally with the laboratory overnight. The seawater sample was added to a Marjo Aerosol Reference Tank (MART) [Stokes et al., 2013], at which point control measurements were made. Guillard's f/2 growth medium with sodium metasilicate [Guillard and Ryther, 1962] was added to the seawater to and light was supplied continuously to (ca. 70 $\mu \mathrm{E} \mathrm{m}$ stimulate algae growth. The seawater was mixed and aerated by introducing large bubble Itered air into the bottom of the tank through $3 \mathrm{~mm}$ diameter Tygon tubing. When the crivephyll-a (chl-a) concentration in the seawater reached an empirically-determined thresture approximately $12 \mathrm{mg} \mathrm{m}^{-3}$, SSA particle generation was commenced. SSA was generated using the plunging waterfall mechanism of the MART [Stokes et al., 2013] for twohour prod, wherein the waterfall was 'pulsed' with a duty cycle of 4 seconds ON and 4 seconds OEF to simulate the episodic nature of a breaking wave in the open ocean [Collins et al., 2014]. S1X, 2 hour periods of SSA generation were performed each day until about 7 days past the timare chl-a concentrations in the seawater bulk returned to baseline values. CCN 
activity measurements presented in this study were conducted at least 3 times and at most once per day during each microcosm experiment.

\section{Results and Discussion}

3.1 Hgropicity of Sea Spray from Laboratory Phytoplankton Blooms

Three labaratory-generated phytoplankton bloom microcosm experiments were conducted within system from which size- and supersaturation-resolved CCN active fractions of SSA a MAK1 system from which size- and supersaturation-resolved CCN active fractions of SSA particle re quantified (see Supplemental Information). Dry particle diameter and critical supers 10 on pairs were used to calculate $\kappa_{a p p}$ for a variety of time points along each bloom microcosm xperiment. The data are separated into three general periods: pre-bloom (after nutrien addition), peak chl-a, and post-bloom (Figure 1a). Overall, $\kappa_{\text {app }}$ averaged $0.95 \pm 0.15$ $(1 \sigma)$ w $(10$ ange of $0.7-1.4$ for all sizes studied (Figure 1b). Measurements of hygroscopicity in laboratory experiments utilizing complex organic matrices like the present study and that of [Fuental., 2011] lack full agreement with in situ SSA generation studies performed in the North Atlantic [Quinn et al., 2014] and the Mediterranean Sea [Schwier et al., 2015] (Figure 1b, gray markers). Differences in production method between this study and Quinn et al. [2014] were rout by direct comparison of the sintered diffusion stone [Bates et al., 2012] and MARTwaterfall methods in the same seawater (Figure S2), as expected based on the findings of Fuentes et al. [2010b]. The aforementioned in situ studies also disagree with one another with respecte response of $\kappa_{a p p}$ to biological activity metrics (e.g., chl-a): the observations of Sch tal. [2015] indicate that $\kappa_{a p p}$ of SSA was only slightly less sensitive to biological 
activity than current parameterizations [e.g., Gantt et al., 2011; Rinaldi et al., 2013] would have predicted, whereas Quinn et al. [2014] observed little-to-no relationship between chl-a and $\kappa_{\text {app }}$ for freshly-produced SSA. Discrepancies between studies using natural seawater could be ascribet to regional differences in organic matter composition and/or microbial community compo

The raror $\kappa_{a p p}$ values obtained in this study agrees well with other laboratory studies of SSA generaldom chemically complex, algae-dominated seawater samples (Figure 2) [Collins et al., 20 3 Fientes et al., 2011; Moore et al., 2011; Wex et al., 2010b]. For particles with $D_{p}<$ $120 \mathrm{~nm}$, all studies on such systems to date have indicated that the CCN-derived $\kappa_{a p p}$ were greater (urarl 0.7 (c.f. Table 1, Collins et al. [2013] and references therein). It should be noted that thenrevious laboratory studies presented in comparison to the work described herein [Collins et al., 2013; Fuentes et al., 2011; Moore et al., 2011; Wex et al., 2010b] use algaeproduced ganic matter samples that were static in composition and produced in monoculture. Any chemical differences documented between samples in those studies are related to either organie matter concentration or source organism. In contrast, the present study differs import from previous efforts due to the use of the Microbial Loop to induce temporally dynam organic matter composition changes in the seawater through natural biochemical interanderonen marine organic matter and the biological community in the seawater [Azam 1983. Lee et al., 2015]. Several groups have posited that chl-a (a metric for phytoplankton et al., 1983. Lee et al., 2015]. Several groups have posited that chl-a (a metric for phytoplankton biomar nay not be a universal basis for parameterizing the properties of nascent SSA [Quinn 
and Bates, 2011; Wang et al., 2015], and that microbial processes are of great importance to shaping the composition and physicochemical properties of nascent SSA [Ault et al., 2013; Collins et al., 2013; O'Dowd et al., 2015; Prather et al., 2013; Wang et al., 2015]. With such arguments in mind, the present study quantified the CCN-derived $\kappa_{\text {app }}$ values of SSA produced from atmed dynamic ecosystem that was initiated from $50 \mu \mathrm{m}$ filtered coastal seawater. -

While bhytoplankton exudate production was likely the most influential process controlling organi mayer composition in monoculture-based studies [Collins et al., 2013; Fuentes et al., 2011; 10 et al., 2011; Wex et al., 2010b], the bloom microcosm experiments presented in this study iochemical processes (e.g., enzyme activity) that influence the organic matter dynamics throughout this type of experiment [Riemann et al., 2000]. Important organic matter processes IItclude not only those associated with primary productivity, like exudate production, but als 1 cosses associated with algae senescence, such as predation by bacteria and viruses, heterotrophic bacterial productivity and metabolism, cell lysis, and bacterial enzyme activity [Azam ana Malfatti, 2007; Pomeroy et al., 2007]. Using a similar chemical system, prior laboratery studies have shown that bacterial processing could be important to SSA composition, mixing state and physicochemical properties [Ault et al., 2013; Collins et al., 2013; Prather et al., 2012wang et al., 2015]. In particular, Collins et al. [2013] showed that bacterial growth on ZoBellmedia in natural seawater was associated with a major decrease in CCN-derived $\kappa_{a p p}$, yet additions or algae monocultures to both bacteria-rich seawater and fresh coastal seawater yielded much smawer depressions of SSA hygroscopicity, similar to the present study. Bacterial 
processing of ZoBell media, rich in peptone and yeast extract, appears to have had a stronger effect on $\kappa_{a p p}$ of SSA than did bacterial degradation of natural algae-produced organic matter, known to be rich in carbohydrates. Comparison of these two mesocosm/microcosm studies, along with the aforementioned comparison between the present study and those of Schwier et al. [2015] inin et al. [2014] suggest that the specific chemical composition of organic matter - -

may inluence the relationship between $\kappa_{a p p}$ and marine microbial activity.

In gen reement with the bloom experiments presented herein, a recent study by Schill et al. [2015] s Pyed a lack of change in the CCN-derived hygroscopicity of SSA for experiments wherein valious representative proxy compounds for marine organic matter were sequentially added MART containing artificial seawater, resulting in an ultimate organic matter concentration of $350 \mu \mathrm{M} \mathrm{C}$. The final concentration of this 'artificial bloom' experiment was Q

similar to the total organic carbon concentration found in the phytoplankton bloom experiments in the present study (Figure S1). Overall, studies using state-of-the-art SSA production methods that range from additions of a few simple proxy compounds to those utilizing complex, phytop-based organic systems have illustrated a common range of CCN-derived hygros opid ty for freshly emitted SSA particles between $\kappa_{\text {app }}=0.7-1.4$.

The small consequence of changing marine biological activity on the CCN-derived particles [Quinn et al., 2015; Russell et al., 2010; Wang et al., 2015]. The insoluble and/or amphri ic nature of the organic components of SSA [Facchini et al., 2008] have led to model 
studies assigning $\kappa_{\text {org }}<0.1$ [Meskhidze et al., 2011; Westervelt et al., 2012]. In the surface ocean, about $60-75 \%$ of organic molecules are less than $1 \mathrm{kDa}$ [Benner, 2002]. With an average molecular weight cited around $4370 \mathrm{~kg} \mathrm{kmol}^{-1}$ [Moore et al., 2008], marine organic matter would, conversely, have an expected $\kappa_{\text {org }}$ value of about 0.006 [Eq. 3, Petters et al., 2009]. The bubble-mentrat SSA production process is well known to be chemically selective [e.g., - -

Hoffm and Duce, 1976], and it has been shown that SSA has a different composition than the seawat from which it formed [Quinn et al., 2015]. Detailed chemical studies have shown that the con syion of SSA particles with $D_{p}<1 \mu \mathrm{m}$ is dominated by fatty acids [e.g., Cochran et al., 20 Fossard et al., 2014; Wang et al., 2015], suggesting that the surface tension of droplets formed from SSA particles could be smaller than that of pure water. Decreased surface tension $\left(\sigma_{l v}\right)$ due to the addition of surface active organic material would cause $\kappa_{a p p}$ to remain higher in only the solute properties of the organic component were acting on the system alone, as is held at $72 \mathrm{mN} \mathrm{m}^{-1}$ in Equation 1 for $\kappa_{a p p}$ by definition. To be clear, the true role of surface tension in cloud droplet activation is under current scrutiny [e.g., Farmer et al., 2015; Pettersand_Kreidenweis, 2013; Prisle et al., 2008; Ruehl et al., 2016]. The potential importance of $\sigma_{l v}$ or SSA particle CCN activation is suggested based on current knowledge of particle compo Itror and the repeated experimental determinations of hygroscopicity in this study with elevater_marine organic matter present. Close inspection of the findings of one experiment in this study (Figures 2 and S2) reveals a 12-18\% increase in $\kappa_{a p p}$ during a subset of the bloom microco experiments. If such an increase in $\kappa_{a p p}$ was due to changes in droplet surface 
tension, it would align with the increasing prevalence surface active compounds during the "peak chl-a' and 'post-senescence' periods of algae blooms [Cochran et al., 2016; Zutic et al., 1981]. Overall, an analysis of the $\kappa_{a p p}$ values from this study indicated that the apparent organic volume fraction $\left(\varepsilon_{a p p, o r g}\right)$ of the SSA particles was less than $0.4\left(D_{p}=30-80 \mathrm{~nm}\right)$ (see Supplemental Informativir, whereas measured organic fractions approaching unity have been noted in nascent -

SSA purticles with $D<200 \mathrm{~nm}$ [Facchini et al., 2008; Prather et al., 2013]. Such discord betwee CON-derived organic content with more direct measures of $\mathrm{CCN}$ could indicate the influen surface tension on cloud droplet activation. Generally speaking, the senescent period algae bloom is characterized by a high diversity of biogeochemical processes within microbial ecosystems [Azam and Malfatti, 2007; Pomeroy et al., 2007], which has been shown to have inmportant impacts on the composition and the enrichment of organic matter in SSA particld De et al., 2015; O'Dowd et al., 2015], including an enrichment of fatty acids in the aerosolychran et al., 2016; Wang et al., 2015].

3.2 Comparison with Primary Marine Organic Aerosol Parameterizations

Ambie osol measurements in the marine boundary layer have suggested a relationship betwee bid ogical activity in the surface ocean and the organic mass fraction of marine aerosol [O'Do@ et al., 2004]. Analysis of submicron aerosol organic mass fraction data from coastal sites focused on a single long-term sampling effort at Mace Head, Ireland, has produced a series of roposed relationships between chl-a and the submicron organic matter fraction in SSA [Eugtes et al., 2010a; Gantt et al., 2011; O'Dowd et al., 2008; Rinaldi et al., 2013; Vignati 
et al., 2010]. Global models use these source function parameterizations to derive not only the organic fraction of SSA, but also can further calculate physicochemical property parameters from the known organic mass fraction in the aerosol, provided some assumptions. As discussed above, the hygroscopicity parameter can be derived from the organic volume fraction of the aeroso 2 shows the $\kappa_{\text {app }}$ values determined in this and similar studies superimposed on the ass med $\kappa$ values as a function of chl-a concentration for a variety of organic mass fraction paramferiz tions (see Supplemental Information). Most parameterizations underestimated $\kappa$ in compa Is $n$ with experiments at nearly all chl-a concentrations studied experimentally. It should be noterting most of the parameterizations were derived from conditions where chl-a $<5 \mathrm{mg} \mathrm{m}^{-}$ ${ }^{3}$, and most. of the experimental data in this study had chl-a $>10 \mathrm{mg} \mathrm{m}^{-3}$ due to technical considerations [Lee et al., 2015]. Still, the CCN activity of SSA in these experiments was not well appromated by the existing organic mass fraction parameterizations. Bulk composition data (andarameterizations derived therefrom) may not be suited to predict the properties of nascent SSA particles as CCN. Unpredicted CCN behavior could result from uncertainties in the interactions of SSA particles with water during cloud droplet activation [Moore et al., 2011; Ovadn vaite et al., 2011] or the insensitivity of aerosol mass measurements to detailed chemical change ciraterosols at CCN-relevant sizes.

3.3 Stay Aerosol Size Distributions and CCN Concentrations

In order to onnect (intensive) aerosol physicochemical properties with the (extensive) expected CCN ber concentrations $\left(N_{C C N}\right)$ at a particular supersaturation, one must closely inspect the 
size distribution of particles [Dusek et al., 2006]. Figure 3 shows the size distribution and sizeresolved cumulative distribution function (CDF) of SSA generated by a laboratory breaking wave, which is nearly identical in shape to the aerosol size distribution generated by the plunging wateriall within the MART [Collins et al., 2014; Stokes et al., 2013]. Superimposed on the size 3 vertical dashed lines that correspond to $D_{a c t}$ for $\kappa$ values of $1,0.1$, and 0.01 , respectively. Changes in hygroscopicity which lead to changes in $D_{a c t}$ that span the peak in the size di (ribu) ion correspond to the highest sensitivity of $N_{C C N}$ to changes in $\kappa$. Since the range of values 19 ) 1 red in this study range was between $\kappa_{a p p}=0.7-1.4$, a change in $D_{a c t}\left(\right.$ or $\kappa_{a p p}$ ) from one extrenty of this range in $\kappa_{a p p}$ to the other (blue vertical band in Figure 3) would not lead to a large changes in $N_{C C N}$. If SSA particle composition changed enough to shift the hygroscopicity through the whole range in $\kappa_{\text {app }}$ observed in the phytoplankton bloom microcosm experiments described this study (as a liberal estimate), the corresponding change in $N_{C C N}$ would be less than $3 \%$ supersaturations relevant to marine clouds $\left(s_{c} \leq 1 \%\right)$. Hence, based on these experiments, one would expect the composition of nascent SSA particles to have a small effect on $N_{C Q}$ haver the ocean.

If biog mically-induced changes in SSA particles were to have a significant impact on cloud proper es in remote marine regions [e.g., McCoy et al., 2015; Quinn and Bates, 2011], it is most likely cherived from changes in the size-resolved emission rate of particles [Alpert et al., 2015; Fuente, 2010a] or through biogenic secondary processes acting on primary SSA [Charlson et al 7; Lana et al., 2012]. Size-resolved studies of the production flux of SSA particles 
have been done previously [de Leeuw et al., 2011; Lewis and Schwartz, 2004] with results that vary to a degree that can strongly influence the findings of global model studies [Tsigaridis et al., 2013]. Alpert et al. [2015] recently used a plunging water jet system to generated SSA from seawater in which a phytoplankton bloom was grown, similar to the present study. It was found that the arotion flux increased approximately 3-fold for particles with $D_{p}<200 \mathrm{~nm}$ during the bloom Based on the $\kappa_{a p p}$ values measured in this and comparable studies (Figure 1), the upper limit v (ue $D_{a c t}$ for nascent SSA would be $125 \mathrm{~nm}\left(s_{c}=0.1 \%, \kappa_{\text {app }}=0.7\right)$. An increase in SSA flux su 1 that observed by Alpert et al. [2015] would therefore translate to an increased flux of CCN a Fuentes et al. [2010a] and Schwier et al. [2015] also showed that regions of the ocean with higher chl- $a$ led to a greater production flux of particles during in situ controlled SSA productronrexperiments using plunging water jet systems. It should be noted that recent studies have son that the formation of a thick foam within laboratory SSA generators through continuos bubble production (like the continuous plunging water jet apparatus) can strongly influence the size distribution and composition of the aerosol when seawater organic matter concentrations are high [Collins et al., 2014; King et al., 2012]. The 'pulsed' operation of the MART in this study reduces the buildup of foam by mimicking the episodic behavior of waves open ocean [Collins et al., 2014]. None of the aforementioned SSA flux studies gave an explicit characterization of foam within the SSA generator during organic matterdependent ux studies; future studies are encouraged to monitor surface conditions. Still, increasing oncentrations of particles with $D_{p}>D_{a c t}$ would explain a primary marine 
contribution to correlated chl- $a$ and cloud drop number concentrations that have been noted in the Southern Ocean [e.g., McCoy et al., 2015; Meskhidze and Nenes, 2006], especially considering the small changes in hygroscopicity observed herein.

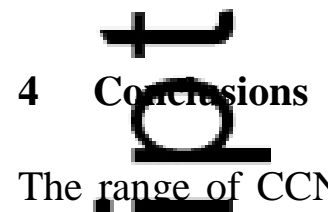

envirolmmen using a pulsed plunging waterfall technique during a set of phytoplankton bloom microcamexperiments was quantified in this study. The overall value of $\kappa_{a p p}$ was observed to remain $($ ealer than 0.7 for all experiments, with an average of 0.95 . In general, these results compare we 1 with chemically simpler laboratory studies in which SSA particles were generated from awater samples doped with algae-produced organic matter, suggesting that overall impact biological activity on SSA $\kappa_{a p p}$ values are relatively weak. The shape of the size distribution from a breaking wave (and from the MART plunging waterfall) dictates that changes in hygre 0 picity within the range observed in this study would only account for up to $3 \%$ change in $N_{C C N}$ for typical marine cloud supersaturations. However, alterations to the SSA production flux for $D_{p}>D_{a c t}$ could help explain observed correlations between biological activityand cloud properties in remote oceanic regions. This is especially evident in light of the relativelv small changes in $\kappa_{a p p}$ associated with large increases in the organic matter concentration and/or status of biological activity of the seawater from which the SSA were generatadinued characterization of the SSA production flux under different marine biog mical states using state-of-the-art SSA generators is warranted. Careful accounting of 
the production of foam within such generators is highly recommended to ensure that conditions for SSA production are well characterized. Chemically-characterized effects on the sizeresolved number flux of particles from the ocean and reconciliation of the discrepancies between production of SSA from in situ studies and those from laboratory experiments should be prioritifore field.

\section{Acrinowledgements}

This stavas conducted within and funded through the Center for Aerosol Impacts on Climate and th 1 ironment (CAICE), a National Science Foundation (NSF) Center for Chemical Innovation CHE-1305427). DBC was supported in part by a fellowship from the Inamori Foundarrand the University of California, San Diego. The authors thank Steven Schill and Gordon Noyak for assistance with various aspects of executing measurements included in this study. Data reported in this study can be found in the cited references or tables in the supporting informatios?

\section{References}

Alpert, Def. W. P. Kilthau, D. W. Bothe, J. C. Radway, J. Y. Aller, and D. A. Knopf (2015), The In luen of Marine Microbial Activities on Aerosol Production: A Laboratory Mesocosm Study, JGeophys Res-Atmos, 120(17), 8841-8860.

Ault_A_R. C. Moffet, J. Baltrusaitis, D. B. Collins, M. J. Ruppel, L. A. Cuadra-Rodriguez, D. F. Zhap, T.رL. Guasco, C. J. Ebben, F. M. Geiger, T. H. Bertram, K. A. Prather, and V. H. Grassian (2013), Size-Dependent Changes in Sea Spray Aerosol Composition and Properties with Dmrerynt Seawater Conditions, Environ Sci Technol, 47(11), 5603-5612.

Azam, F., and F. Malfatti (2007), Microbial Structuring of Marine Ecosystems, Nat Rev Microbio, 5(10), 782-791. 
Azam, F., T. Fenchel, J. G. Field, J. S. Gray, L. A. Meyerreil, and F. Thingstad (1983), The Ecological Role of Water-Column Microbes in the Sea, Mar Ecol Prog Ser, 10(3), 257-263.

Bates, T. S., P. K. Quinn, A. A. Frossard, L. M. Russell, J. Hakala, T. Petaja, M. Kulmala, D. S. Covert, C. D. Cappa, S. M. Li, K. L. Hayden, I. Nuaaman, R. McLaren, P. Massoli, M. R. Canagaratna, T. B. Onasch, D. Sueper, D. R. Worsnop, and W. C. Keene (2012), Measurements of Oedn_thed Aerosol Off the Coast of California, J Geophys Res-Atmos, 117, D00v15.

Benner R. (2002), Chemical Composition and Reactivity, in Biogeochemistry of Marine Dissol ganic Matter, edited by D. A. a. C. A. C. Hansell, Elsevier Science (USA), San Diego

Carsla S., L. A. Lee, C. L. Reddington, K. J. Pringle, A. Rap, P. M. Forster, G. W. Mann, D. V. Spracklen, M. T. Woodhouse, L. A. Regayre, and J. R. Pierce (2013), Large Contribution of Natucal_erosols to Uncertainty in Indirect Forcing, Nature, 503(7474), 67-71.

Charls A. J., J. E. Lovelock, M. O. Andreae, and S. G. Warren (1987), Oceanic Phytoptrikeon, Atmospheric Sulfur, Cloud Albedo and Climate, Nature, 326(6114), 655-661.

Cochran, R. E., O. Laskina, T. Jayarathne, A. Laskin, J. Laskin, P. Lin, C. M. Sultana, C. Lee, K. A. Moore, C. D. Cappa, T. H. Bertram, K. A. Prather, V. H. Grassian, and E. A. Stone (2016), Analys or Organic Anionic Surfactants in Fine and Coarse Fractions of Freshly Emitted Sea Spray Crocol, Envion. Sci. Technol., 50(5), 2477-2486.

Collin P. B., D. F. Zhao, M. J. Ruppel, O. Laskina, J. R. Grandquist, R. L. Modini, M. D. Stokes, L. Russell, T. H. Bertram, V. H. Grassian, G. B. Deane, and K. A. Prather (2014), Dire Chemical Composition Measurements to Evaluate the Physicochemical Differencos between Controlled Sea Spray Aerosol Generation Schemes, Atmos Meas Tech, 7(11) $2067-3683$.

Collins, D. B., A. P. Ault, R. C. Moffet, M. J. Ruppel, L. A. Cuadra-Rodriguez, T. L. Guasco, C. E. Corrigan, B. E. Pedler, F. Azam, L. I. Aluwihare, T. H. Bertram, G. C. Roberts, V. H. Grassian, and K. A. Prather (2013), Impact of Marine Biogeochemistry on the Chemical Mixing State a a goud Forming Ability of Nascent Sea Spray Aerosol, J Geophys Res-Atmos, 118(15), $8553-8 \div 65$

Cubiso I, M. J., B. Ervens, G. Feingold, K. S. Docherty, I. M. Ulbrich, L. Shields, K. Prather, S. Hering J. L. Jimenez (2008), The Influence of Chemical Composition and Mixing State of Los Urban Aerosol on Ccn Number and Cloud Properties, Atmos Chem Phys, 8(18), $5649-5667$.

de Leeww., E. L. Andreas, M. D. Anguelova, C. W. Fairall, E. R. Lewis, C. O'Dowd, M. Schulz, and S. E. Schwartz (2011), Production Flux of Sea Spray Aerosol, Rev Geophys, 49, RG201. 
Dusek, U., G. P. Frank, L. Hildebrandt, J. Curtius, J. Schneider, S. Walter, D. Chand, F. Drewnick, S. Hings, D. Jung, S. Borrmann, and M. O. Andreae (2006), Size Matters More Than Chemistry for Cloud-Nucleating Ability of Aerosol Particles, Science, 312(5778), 1375-1378.

Facchini, M. C., M. Rinaldi, S. Decesari, C. Carbone, E. Finessi, M. Mircea, S. Fuzzi, D. Ceburnis, R. Flanagan, E. D. Nilsson, G. de Leeuw, M. Martino, J. Woeltjen, and C. D. O'Dowd (2008) Drishary Submicron Marine Aerosol Dominated by Insoluble Organic Colloids and Aggregatac Geophys Res Lett, 35(17), L17814.

Farmer, C. D. Cappa, and S. M. Kreidenweis (2015), Atmospheric Processes and Their Controlling-Influence on Cloud Condensation Nuclei Activity, Chem Rev, 115(10), 4199-4217.

Feingo W. R. Cotton, S. M. Kreidenweis, and J. T. Davis (1999), The Impact of Giant Cloud Gor ensation Nuclei on Drizzle Formation in Stratocumulus: Implications for Cloud Radiatke Poperties, J Atmos Sci, 56(24), 4100-4117.

Frossa A, A.A., L. M. Russell, S. M. Burrows, S. M. Elliott, T. S. Bates, and P. K. Quinn (2014), Sources and Composition of Submicron Organic Mass in Marine Aerosol Particles, J Geophys Res-Atmovo, 19(22), 12977-13003.

Fuentes, E., H. Coe, D. Green, and G. McFiggans (2011), On the Impacts of PhytoplanktonDerive Organic Matter on the Properties of the Primary Marine Aerosol - Part 2: Composition, Hygrosnnicity and Cloud Condensation Activity, Atmos Chem Phys, 11(6), 2585-2602.

Fuente E., H. Coe, D. Green, G. de Leeuw, and G. McFiggans (2010a), On the Impacts of Phytopan 3 -Derived Organic Matter on the Properties of the Primary Marine Aerosol - Part 1: Soun Atmos Chem Phys, 10(19), 9295-9317.

Fuentes H. Coe, D. Green, G. de Leeuw, and G. McFiggans (2010b), Laboratory-Generated Primary matine Aerosol Via Bubble-Bursting and Atomization, Atmos Meas Tech, 3(1), 141162.

Gantt, N Meskhidze, M. C. Facchini, M. Rinaldi, D. Ceburnis, and C. D. O'Dowd (2011), Wind Speed Dependent Size-Resolved Parameterization for the Organic Mass Fraction of Sea Spray erosbl, Atmos Chem Phys, 11(16), 8777-8790.

Gantt, PـIu, N. Meskhidze, Y. Zhang, A. Nenes, S. J. Ghan, X. Liu, R. Easter, and R. Zaveri (2012) Global Distribution and Climate Forcing of Marine Organic Aerosol - Part 2: Effects on Cloud Properties and Radiative Forcing, Atmos Chem Phys, 12(14), 6555-6563.

Glantz P (2010), Satellite Retrieved Cloud Optical Thickness Sensitive to Surface Wind Speed in the Subar tic Marine Boundary Layer, Environ Res Lett, 5(3), 034002.

Guillard,R., and J. H. Ryther (1962), Studies of Marine Planktonic Diatoms .1. Cyclotella Nana-us fedt, and Detonula Confervacea (Cleve) Gran, Can J Microbiol, 8(2), 229-239. 
Hoffman, E. J., and R. A. Duce (1976), Factors Influencing Organic-Carbon Content of Marine Aerosols - Laboratory Study, J Geophys Res-Oc Atm, 81(21), 3667-3670.

King, S. M., A. C. Butcher, T. Rosenoern, E. Coz, K. I. Lieke, G. de Leeuw, E. D. Nilsson, and M. Bilde (2012), Investigating Primary Marine Aerosol Properties: Ccn Activity of Sea Salt and Mixed Inorganic-Organic Particles, Environ Sci Technol, 46(19), 10405-10412.

Lana, A., R. Simo, S. M. Vallina, and J. Dachs (2012), Potential for a Biogenic Influence on Cloud Mlicr physics over the Ocean: A Correlation Study with Satellite-Derived Data, Atmos Chem Ango, 17), 7977-7993.

Lee, C C. M. Sultana, D. B. Collins, M. V. Santander, J. L. Axson, F. Malfatti, G. C. Cornwell, J. R. G Advanging Model Systems for Fundamental Laboratory Studies of Sea Spray Aerosol Using the MicrobalLop, J Phys Chem A, 119(33), 8860-8870.

Lewis, E R, and S. E. Schwartz (2004), Sea Salt Aerosol Production: Mechanisms, Methods, Measurements and Models - a Critical Review, American Geophysical Union, Washington, DC.

McCoy, D. T., S. M. Burrows, R. Wood, D. P. Grosvenor, S. M. Elliott, P.-L. Ma, P. J. Rasch, and D. L. Fartmann (2015), Natural Aerosols Explain Seasonal and Spatial Patterns of Southern Ocean coud Albedo, Science Adv., 1(6), e1500157.

Meskhidze, N., and A. Nenes (2006), Phytoplankton and Cloudiness in the Southern Ocean, Scienc CI\&(5804), 1419-1423.

Meskhidze.N., J. Xu, B. Gantt, Y. Zhang, A. Nenes, S. J. Ghan, X. Liu, R. Easter, and R. Zaveri (2011) Global Distribution and Climate Forcing of Marine Organic Aerosol: 1. Model Improvements and Evaluation, Atmos Chem Phys, 11(22), 11689-11705.

Moore, M. J. K., H. Furutani, G. C. Roberts, R. C. Moffet, M. K. Gilles, B. Palenik, and K. A. Prather (2011), Effect of Organic Compounds on Cloud Condensation Nuclei (Ccn) Activity of Sea Sp nusurosol Produced by Bubble Bursting, Atmos Environ, 45(39), 7462-7469.

Moore R. J., E. D. Ingall, A. Sorooshian, and A. Nenes (2008), Molar Mass, Surface Tension, and Droplow Growth Kinetics of Marine Organics from Measurements of Ccn Activity, Geophys Res Let 25(7), L07801.

O'Dowu, C., D. Ceburnis, J. Ovadnevaite, J. Bialek, D. B. Stengel, M. Zacharias, U. Nitschke, S. Connol Rinaldi, S. Fuzzi, S. Decesari, M. C. Facchini, S. Marullo, R. Santoleri, A. Dell'Anno_C. Corinaldesi, M. Tangherlini, and R. Danovaro (2015), Connecting Marine Productivity to Sea-Spray Via Nanoscale Biological Processes: Phytoplankton Dance or Death Disco?,Scl.Rep., 5, 14883. 
O'Dowd, C. D., B. Langmann, S. Varghese, C. Scannell, D. Ceburnis, and M. C. Facchini (2008), A Combined Organic-Inorganic Sea-Spray Source Function, Geophys Res Lett, 35(1), L01801.

O'Dowd, C. D., M. C. Facchini, F. Cavalli, D. Ceburnis, M. Mircea, S. Decesari, S. Fuzzi, Y. J. Yoon, and J. P. Putaud (2004), Biogenically Driven Organic Contribution to Marine Aerosol, Natun:121009), 676-680.

Ovadn vaito J., D. Ceburnis, G. Martucci, J. Bialek, C. Monahan, M. Rinaldi, M. C. Facchini, H. Ben D. R. Worsnop, and C. O'Dowd (2011), Primary Marine Organic Aerosol: A Dichot Low Hygroscopicity and High Ccn Activity, Geophys Res Lett, 38, L21806.

Padro, T. R. H. Moore, X. Zhang, N. Rastogi, R. J. Weber, and A. Nenes (2012), Mixing State apd Compositional Effects on Ccn Activity and Droplet Growth Kinetics of Size-Resolved Ccn in Un ban Environment, Atmos Chem Phys, 12(21), 10239-10255.

Petters 1. D., and S. M. Kreidenweis (2007), A Single Parameter Representation of Hygrostopic Growth and Cloud Condensation Nucleus Activity, Atmos Chem Phys, 7(8), 19611971.

Petters, Mr. D., and S. M. Kreidenweis (2013), A Single Parameter Representation of Hygrocopie Growth and Cloud Condensation Nucleus Activity - Part 3: Including Surfactant Partiticing Atmos Chem Phys, 13(2), 1081-1091.

Petters 1Y. P., S. M. Kreidenweis, A. J. Prenni, R. C. Sullivan, C. M. Carrico, K. A. Koehler, and P. \$. Wemann (2009), Role of Molecular Size in Cloud Droplet Activation, Geophys Res Lett,

Pomeroy. R., P. J. I. Williams, F. Azam, and J. E. Hobbie (2007), The Microbial Loop, Ocedrugraphy, 20(2), 28-33.

Prather, K. A., T. H. Bertram, V. H. Grassian, G. B. Deane, M. D. Stokes, P. J. DeMott, L. I. Aluwilune P. Palenik, F. Azam, J. H. Seinfeld, R. C. Moffet, M. J. Molina, C. D. Cappa, F. M. Geiger G. C. Roberts, L. M. Russell, A. P. Ault, J. Baltrusaitis, D. B. Collins, C. E. Corrigan, L. A. (uadr)-Rodriguez, C. J. Ebben, S. D. Forestieri, T. L. Guasco, S. P. Hersey, M. J. Kim, W. F. Lamber, R. L. Modini, W. Mui, B. E. Pedler, M. J. Ruppel, O. S. Ryder, N. G. Schoepp, R. C. Sulliva , and D. F. Zhao (2013), Bringing the Ocean into the Laboratory to Probe the Chemical Compung Sea Spray Aerosol, P Natl Acad Sci USA, 110(19), 7550-7555.

Prisle, N. L., T. Raatikainen, R. Sorjamaa, B. Svenningsson, A. Laaksonen, and M. Bilde (2008), Surfactant artitioning in Cloud Droplet Activation: A Study of C8, C10, C12 and C14 Normal Fatty Acidedium Salts, Tellus B, 60(3), 416-431.

Quinn K., and T. S. Bates (2011), The Case against Climate Regulation Via Oceanic Phytopw kton Sulphur Emissions, Nature, 480(7375), 51-56. 
Quinn, P. K., D. B. Collins, V. H. Grassian, K. A. Prather, and T. S. Bates (2015), Chemistry and Related Properties of Freshly Emitted Sea Spray Aerosol, Chem Rev, 115(10), 4383-4399.

Quinn, P. K., T. S. Bates, K. S. Schulz, D. J. Coffman, A. A. Frossard, L. M. Russell, W. C. Keene, and D. J. Kieber (2014), Contribution of Sea Surface Carbon Pool to Organic Matter Enrichment in Sea Spray Aerosol, Nat Geosci, 7(3), 228-232.

Ramanathan, V., P. J. Crutzen, J. T. Kiehl, and D. Rosenfeld (2001), Atmosphere - Aerosols, Climat, and the Hydrological Cycle, Science, 294(5549), 2119-2124.

Riemann, L., G. F. Steward, and F. Azam (2000), Dynamics of Bacterial Community Composition and Activity During a Mesocosm Diatom Bloom, Appl Environ Microb, 66(2), $578-58$

Rinald M.)S. Fuzzi, S. Decesari, S. Marullo, R. Santoleri, A. Provenzale, J. von Hardenberg, D. Ceburnis, A. Vaishya, C. D. O'Dowd, and M. C. Facchini (2013), Is Chlorophyll-a the Best Surrog Ae Mr Organic Matter Enrichment in Submicron Primary Marine Aerosol?, J Geophys Res-Atmos, 18(10), 4964-4973.

Roelofs, G. J. (2008), A Gcm Study of Organic Matter in Marine Aerosol and Its Potential Contribution to Cloud Drop Activation, Atmos Chem Phys, 8(3), 709-719.

Ruehl, C. R., J. F. Davies, and K. R. Wilson (2016), An Interfacial Mechanism for Cloud Droplet Formation on Organic Aerosols, Science, 351(6280), 1447-1450.

Ruehl, C.B. P. Y. Chuang, A. Nenes, C. D. Cappa, K. R. Kolesar, and A. H. Goldstein (2012), Strong Evidence of Surface Tension Reduction in Microscopic Aqueous Droplets, Geophys Res Lett, J

Russ M., L. N. Hawkins, A. A. Frossard, P. K. Quinn, and T. S. Bates (2010), Carbohydrate-Like Composition of Submicron Atmospheric Particles and Their Production from Ocean Bubble Bursting, P Natl Acad Sci USA, 107(15), 6652-6657.

Schill, S. R., D. B. Collins, C. Lee, H. S. Morris, G. A. Novak, K. A. Prather, P. K. Quinn, C. M. Sultan, A. Y. Tivanski, K. Zimmermann, C. D. Cappa, and T. H. Bertram (2015), The Impact of Aeroso Dolicle Mixing State on the Hygroscopicity of Sea Spray Aerosol, ACS Cent. Sci., 1(3), $132-1$

Schwrer, A. N., C. Rose, E. Asmi, A. M. Ebling, W. M. Landing, S. Marro, M. L. Pedrotti, A. Sallowculano, S. Agusti, A. Tsiola, P. Pitta, J. Louis, C. Guieu, F. Gazeau, and K. Sellegri (2015)_Primary Marine Aerosol Emissions from the Mediterranean Sea During Pre-Bloom and Oligotrophid Conditions: Correlations to Seawater Chlorophyll a from a Mesocosm Study, Atmos Chem Phys, 15(14), 7961-7976. 
Stokes, M. D., G. B. Deane, K. Prather, T. H. Bertram, M. J. Ruppel, O. S. Ryder, J. M. Brady, and D. Zhao (2013), A Marine Aerosol Reference Tank System as a Breaking Wave Analogue for the Production of Foam and Sea-Spray Aerosols, Atmos Meas Tech, 6(4), 1085-1094.

Straub, D. J., T. Lee, and J. L. Collett (2007), Chemical Composition of Marine Stratocumulus Clouds over the Eastern Pacific Ocean, J Geophys Res-Atmos, 112(D4), D04307.

Sullivah, R. C., M. J. K. Moore, M. D. Petters, S. M. Kreidenweis, G. C. Roberts, and K. A. Prathe (2099), Effect of Chemical Mixing State on the Hygroscopicity and Cloud Nucleation Proper Galcium Mineral Dust Particles, Atmos Chem Phys, 9(10), 3303-3316.

Tsigaridis, K., D. Koch, and S. Menon (2013), Uncertainties and Importance of Sea Spray Comp on Aerosol Direct and Indirect Effects, J Geophys Res-Atmos, 118(1), 220-235.

Twohy C. H., and J. R. Anderson (2008), Droplet Nuclei in Non-Precipitating Clouds: Compostron and Size Matter, Environ Res Lett, 3(4), 045002.

Vignat . M. C. Facchini, M. Rinaldi, C. Scannell, D. Ceburnis, J. Sciare, M. Kanakidou, S. Myriokefalitakis, F. Dentener, and C. D. O'Dowd (2010), Global Scale Emission and Distribution of Sea-Spray Aerosol: Sea-Salt and Organic Enrichment, Atmos Environ, 44(5), 670-677.

Wang, X., C. M. Sultana, J. Trueblood, T. C. J. Hill, F. Malfatti, C. Lee, O. Laskina, K. A. Moore, C. M. Beall, C. S. McCluskey, G. C. Cornwell, Y. Zhou, J. L. Cox, M. A. Pendergraft, M. V. aptánder, T. H. Bertram, C. D. Cappa, F. Azam, P. J. DeMott, V. H. Grassian, and K. A. Prather 2015), Microbial Control of Sea Spray Aerosol Composition: A Tale of Two Blooms, ACS

Westerver, D. M., R. H. Moore, A. Nenes, and P. J. Adams (2012), Effect of Primary Organic Sea spray Emissions on Cloud Condensation Nuclei Concentrations, Atmos Chem Phys, 12(1), 89-101.

Wex, G_McFiggans, S. Henning, and F. Stratmann (2010a), Influence of the External Mixing

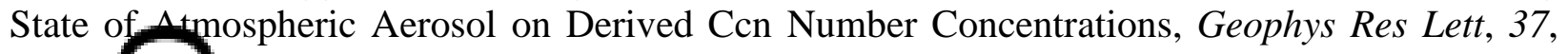
L1080

Wex, Huentes, G. Tsagkogeorgas, J. Voigtlander, T. Clauss, A. Kiselev, D. H. Green, H. Coe, McFiggans, and F. Stratmann (2010b), The Influence of Algal Exudate on the Hygroscopicity of Sea Spray Particles, Adv Meteorol, 365131.

Woodcock_A. H. (1952), Atmospheric Salt Particles and Raindrops, J Meteorol, 9(3), 200-212.

Zutic, Cosovic, E. Marcenko, N. Bihari, and F. Krsinic (1981), Surfactant Production by Marine-Phyoplankton, Mar Chem, 10(6), 505-520. 


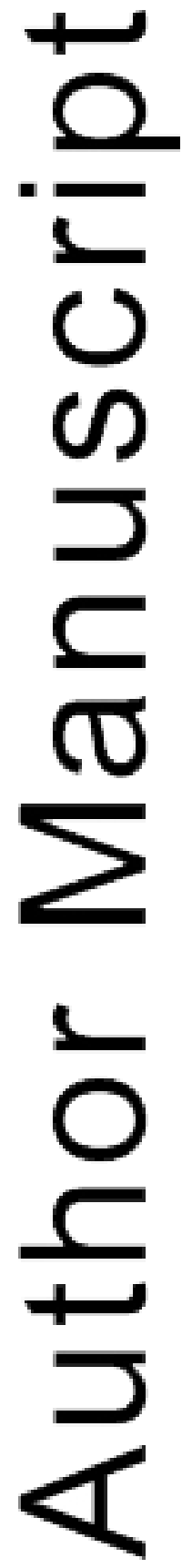

This article is protected by copyright. All rights reserved. 
Figure 1: (a) General scheme for the growth of phytoplankton, bacteria, and viruses within a MART microcosm with Pre-peak chl-a, Peak chl-a, and Post-peak chl-a periods labeled. (b) Hygroscopicity of nascent SSA particles from a variety of laboratory and field studies, segregatea by dry particle diameter. Measurements presented in this study are shown as triangle ars are coordinated with (a). The method by which the sample was generated is - in parentheses. Data from the North Atlantic are from Quinn et al. [2014], Ostreococcus (Ostr.) and Synechococcus (Synech.) are from Moore et al. [2011] (highest organic matter concentratins), and Dunaliella tertiolecta monoculture from Collins et al. [2013]. Shading for algal exudates from Fuentes et al. [2011] and Wex et al. [2010b] represents the range of values obtained trom various algae utilized. Key details on each study are noted in the text.
$\subset$
$\sqrt{6}$

Figure 2: Selected SSA organic mass fraction parameterizations based on measured ocean surface concentration, translated into $\kappa$ values (see Supporting Information). Measured $\kappa_{\text {app }}$ values from this and prior studies of nascent SSA have been superimposed for comparison.
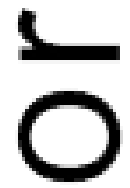

Figure (a.) Number size distribution of nascent SSA from wave breaking (top) and the "inverted" gumulative distribution (CDF) of the same data (bottom). The inverted CDF is the integral of ye size distribution between a size $\left(D_{p}\right)$ and the upper limit of the distribution. When evaluated the activation diameter $\left(D_{a c t}\right)$, the inverted CDF represents the number concentration 
of $\mathrm{CCN}$ expected $\left(N_{C C N}\right)$. The vertical red dashed lines indicate $D_{a c t}$ for a $\kappa$ value that is labeled at the base of the figure when $s_{c}=0.4 \%$. The blue shaded band indicates the full range of $\kappa_{\text {app }}$ values $(0.7-1.4)$ observed in the MART microcosm bloom experiments. (b.) Percentage change in total $N_{C C N}$ for the wave breaking size distribution when considering a hypothetical change in hygroseopicity from a reference state of $\kappa=0.8$ to the value shown on the horizontal axis. -

Contol lines are superimposed to help guide the eye; line color changes from black to white only to max mize contrast.
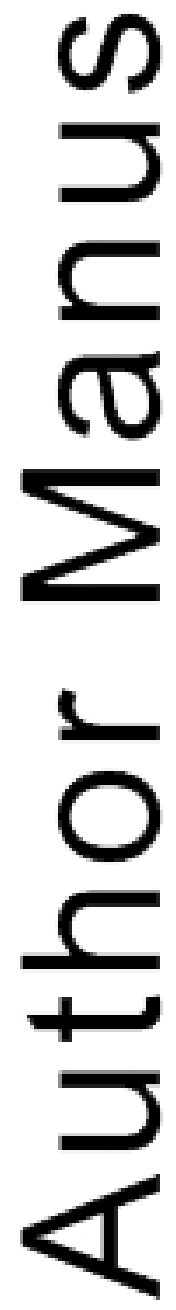


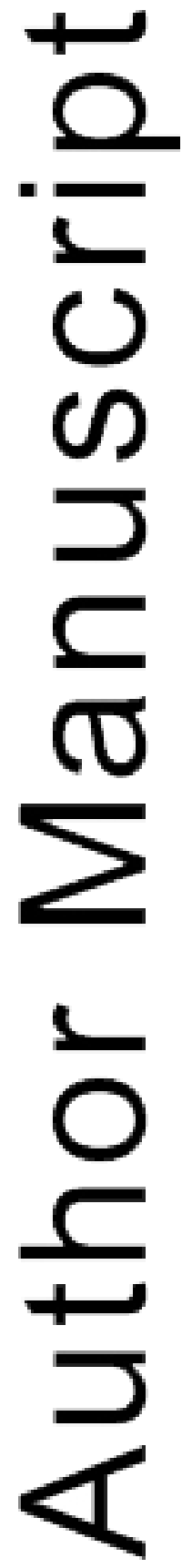

This article is protected by copyright. All rights reserved. 
(a)

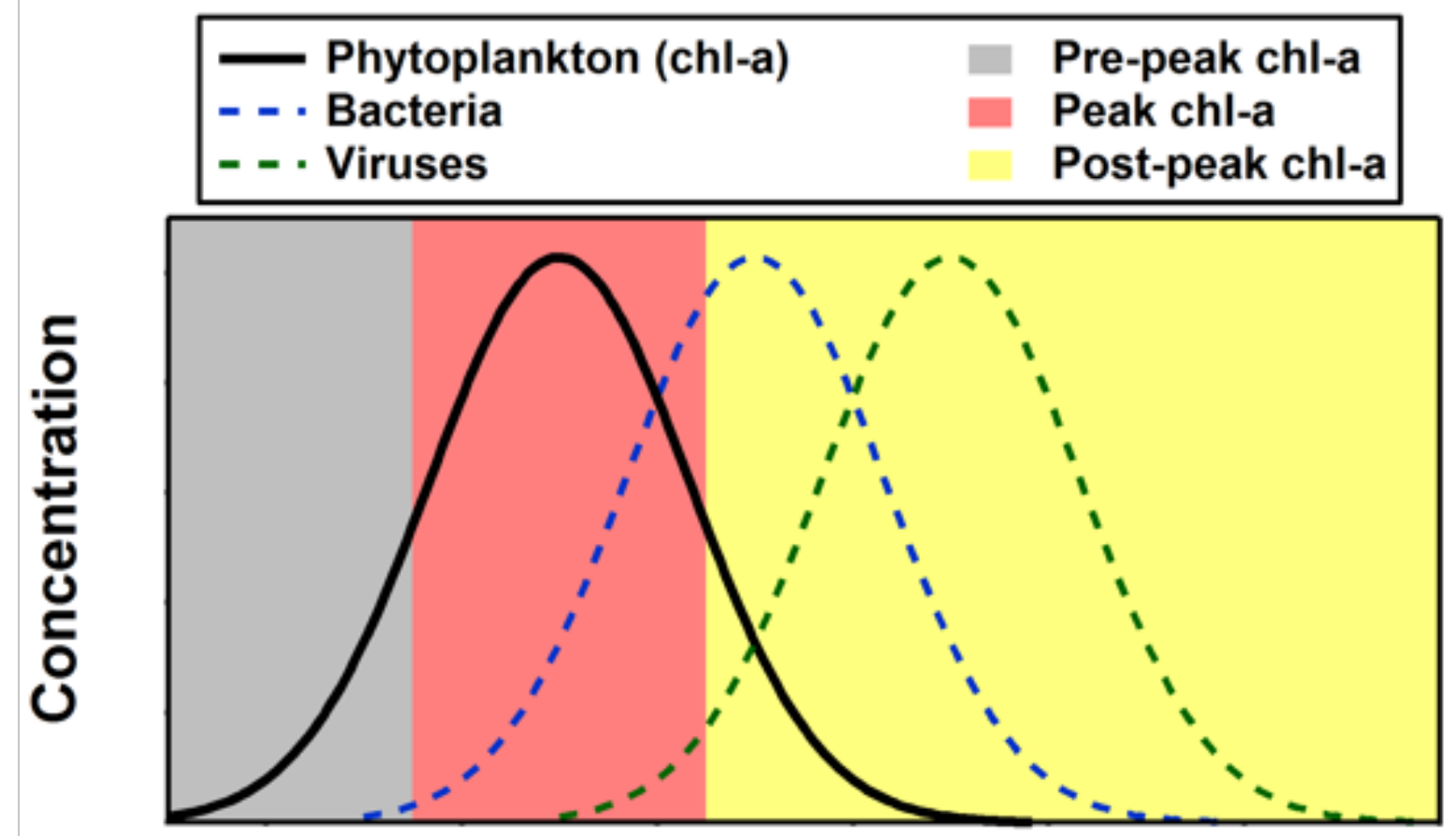

(b)

\section{Time}

- - $\mathrm{NaCl}$ (Aerosol Inorganics Model) Algal Exudates (Plunging Jet)

Ostr. $\times$ Synech. (SGF) Dunaliella (Lab Wave Breaking)

- N. Atlantic (Sea Sweep) - Mediterranean Sea (Plunging Jet)

Phytoplankton Microcosms (MART) [this work]

$\Delta$ Pre $\Delta$ Peak $\triangle$ Post

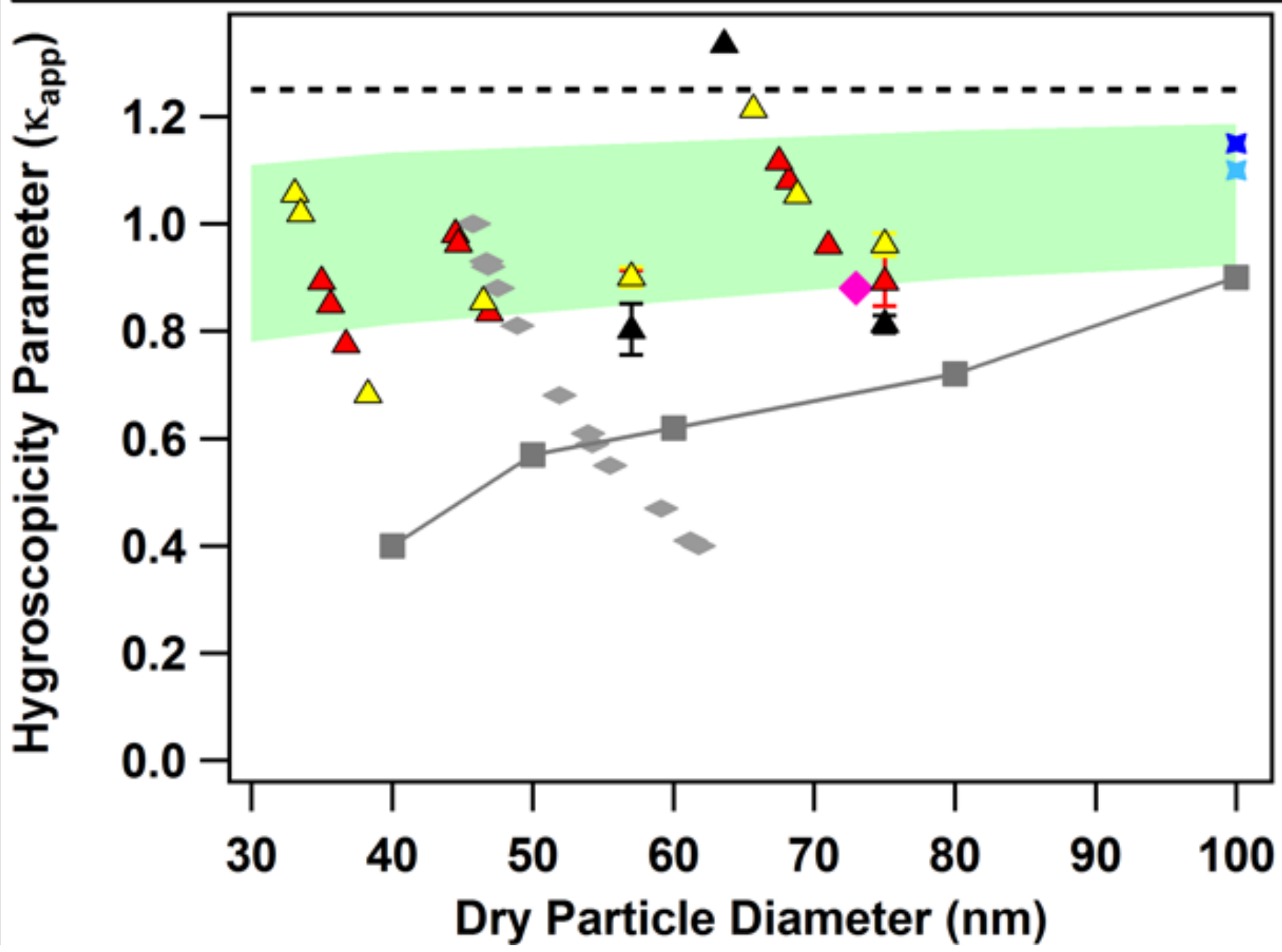

2016GL069922-f01-z-.png

This article is protected by copyright. All rights reserved. 
.... NaCl (Aerosol Inorganics Model)

Parameterizations of $\kappa$ versus chl-a

— Phytoplankton Exudates [Fuentes et al., 2011]

— Point Reyes, Sigmoid [Gantt et al., 2011]

— Mace Head, Sigmoid [Gantt et al., 2011]

— Mace Head, 8 day lag [Rinaldi et al., 2013]

Mace Head [Vignati et al., 2010]

Experimental $\kappa_{\text {app }}$ values

- This study

- Dunaliella tertiolecta [Collins et al., 2013]

+ Algal Exudates [Fuentes et al., 2011]

$\square$ Mediterranean Sea [Schwier et al., 2015]

North Atlantic Ocean [Quinn et al., 2014]

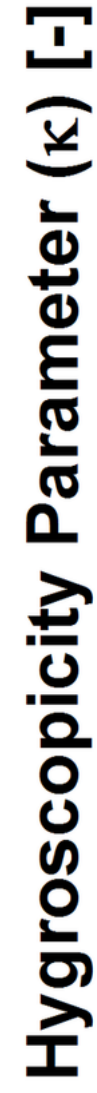

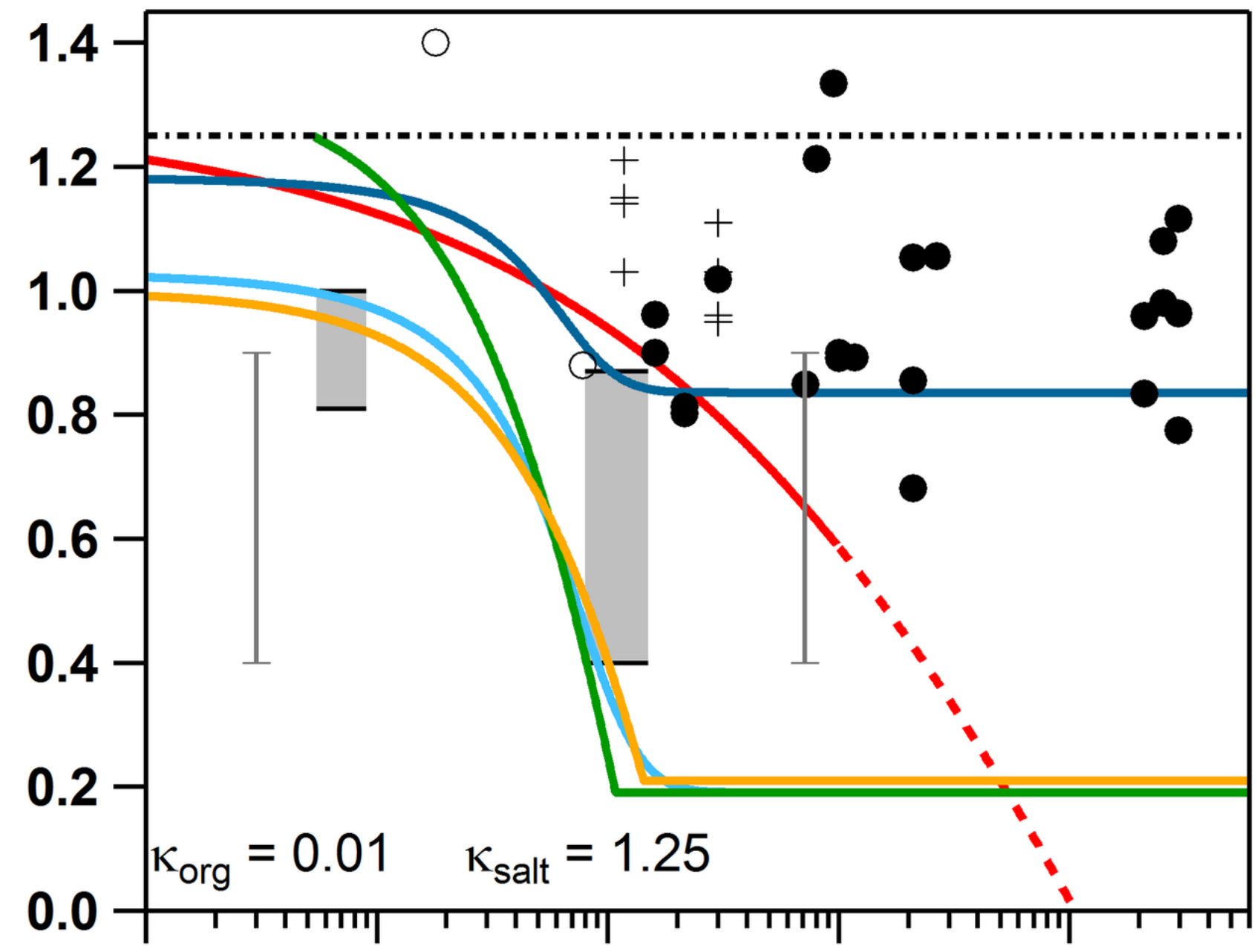

0.01

0.1

1

10

100 


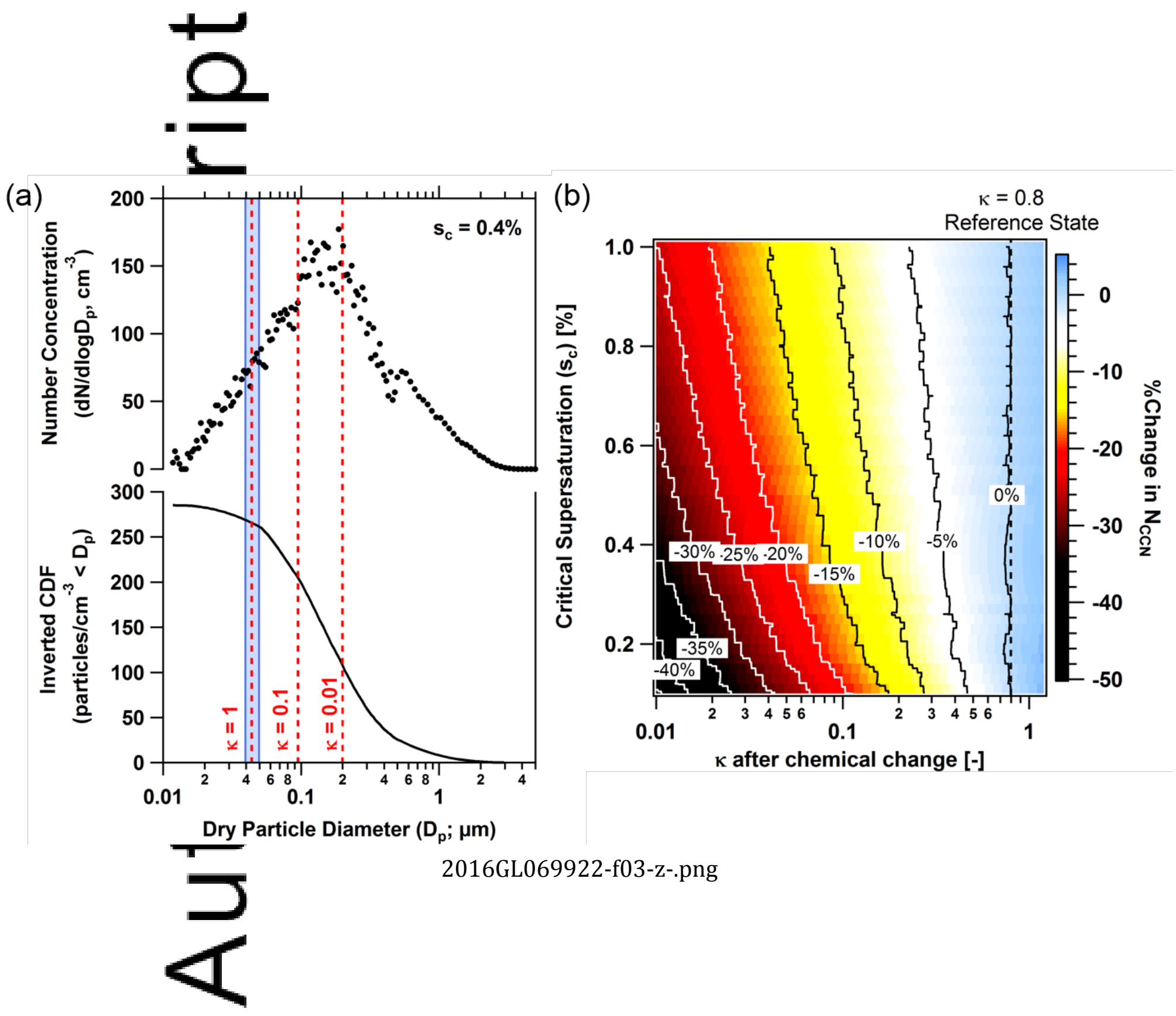

This article is protected by copyright. All rights reserved. 